\title{
EFEKTIVITAS PENERAPAN PENDEKATAN PEMBELAJARAN LIFE SKILLS TERHADAP HASIL BELAJAR SISWA POKOK BAHASAN GARIS SINGGUNG LINGKARAN KELAS VIII SMP NEGERI 4 MATARAM TAHUN PELAJARAN 2013/2014
}

\author{
${ }^{1}$ Abdillah, ${ }^{2}$ Syaefudin suhaedi, ${ }^{3}$ Amanah Andriani \\ 1,2 Dosen Program Studi Pendidikan Matematika Universitas Muhammadiyah Mataram \\ ${ }^{3}$ Mahasiswa Sarjana Program Studi Pendidikan Matematika Universitas Muhammadiyah Mataram
}

\begin{abstract}
ABSTRAK
Penelitian ini bertujuan untuk mengetahui Efeketivitas penerapan pendekatan dalam pembelajaran terhadap hasil belajar siswa yang diajar dengan menggunakan metode pembelajaran dengan pendekatan Life Skills dan siswa yang diajar dengan menggunakan metode konvensional pada materi pokok Garis Singgung lingkaran kelas VIII di SMP Negeri 4 Mataram, dan untuk mengetahui metode mana yang lebih baik untuk digunakan dalam pembelajaran Matematika pada materi pokok garis singgung lingkaran. Populasi penelitian adalah siswa kelas VIII semester II yang terdiri dari 8 kelas yaitu kelas $\mathrm{VIII}^{1}, \mathrm{VIII}^{2}, \mathrm{VIII}^{3}, \mathrm{VIII}^{4}, \mathrm{VIII}^{5}, \mathrm{VIII}^{6}, \mathrm{VIII}^{7}, \mathrm{VIII}^{8}$, dengan teknik Purposive sampling dipilih kelas $\mathrm{VIII}^{2}$ sebagai kelas kontrol dan kelas VIII ${ }^{4}$ sebagai kelas eksperimen. Pengumpulan data dilakukan melalui tes hasil belajar. Teknik analisis data yang dilakukan adalah uji persyaratan analisis dengan uji normalitas, uji homogenitas, dan uji hipotesis dengan Uji-T. Berdasarkan analisis data hasil belajar diperoleh ratarata kelas ekperimen $(58,90)$ lebih tinggi daripada rata-rata kelas kontrol $(51,25)$. Pada uji normalitas dan homogenitas juga diketahui bahwa kelas eksperimen dan kelas kontrol berdistribusi normal dan homogen. Setelah dilakujan uji t diperoleh nilai thitung sebesar 2,5483 sedangkan ttabel pada taraf signifikan 0,05 sebesar 1,994. Karena thitung $>$ tabel maka $\mathrm{H}_{0}$ di tolak dan $\mathrm{H}_{1}$ diterima, artinya terdapat perbedaan hasil belajar antara siswa kelas eksperimen yang diajar dengan menggunakan motode pembelajaran dengan pendekatan Life Skills dan siswa yang diajar dengan menggunkan metode pembelajaran konvensional. di mana, hasil belajar siswa yang diajar dengan metode pembelajaran dengan pendekatan Life Skills lebih daik daripada hasil belajar siswa yang diajar dengan metode pembelajaran konvensional.
\end{abstract}

Kata kunci: Metode pembelajaran dengan pendekatan Life Skills, metode konvensional, hasil belajar, Garis singgung lingkaran

\section{PENDAHULUAN}

Salah satu wadah bagi upaya peningkatan kualitas sumber daya manusia adalah dalam bidang pendidikan. Ada beberapa indikator dalam peningkatan mutu pendidikan antara lain melalui peningkatan kinerja guru dan peningkatan mutu pembelajaran. Apabila kita mengamati perkembangan pembelajaran matematika di Indonesia sangat memprihatinkan, karena rendahnya penguasaan teknologi dan kemampuan sumber daya manusia Indonesia untuk berkompetensi secara global. Di tambah lagi dengan masih rendahnya kemampuan anak Indonesia di bidang matematika, mereka beranggapan bahwa pembelajaran matematika itu sulit, serta kurangnya jumlah pengajar yang mengikuti perkembangan matematika. Sebaiknya pihak sekolah, guru, siswa dan pemerhati pendidikan, pemerintah, lebih peduli pada pembelajaran matematika di Indonesia sehingga dapat memberikan dampak yang positif bagi kemajuan pembelajaran matematika di Indonesia.

Berdasarkan hasil pengamatan pada saat observasi awal di SMPN 4 Mataram, ditemukan bahwa siswa menganggap matematika adalah pelajaran yang sulit dan menakutkan, sehingga partisipasi siswa untuk mengemukakan konsep dan menemukan sendiri pemecahan masalah masih kurang. Hal ini berdampak pada hasil belajar siswa yang terdata pada nilai kelas VIII semester II tahun pelajaran 2012/2013. Ketuntasan secara klasikal dari hasil belajar siswa hanya mencapai $18,92 \%$ ini masih jauh dari ketuntasan klasikal yang ditentukan yakni sebesar $75 \%$ sedangkan nilai rata-rata yang 
diperoleh sebesar 58,27 di bawah dari KKM yang ditentukan oleh sekolah yaitu sebesar 73 .

Data tersebut merupakan data dari tahun yang lalu, maka peneliti melakukan tes terkait dengan materi prasyarat garis singgung lingkaran. Tes terkait materi prasyarat menyangkut dengan bagian segitiga siku-siku, operasi-operasi hitung, seperti perkalian, pembagian dan penyederhanaan.

Pembelajaran matematika hendaknya lebih bervariasi metode maupun strateginya guna mengoptimalkan potensi siswa. Upayaupaya guru dalam mengatur berbagai pembelajaran merupakan bagian penting dalam keberhasilan siswa mencapai tujuan yang direncanakan karena itu pemilihan metode, strategi dari pendekatan dalam mendesain model pembelajaran guna tercapainya iklim pembelajaran aktif yang bermakna adalah tuntutan yang mesti dipenuhi para guru.

Dalam setiap kesempatan pembelajaran matematika hendaknya dimulai dengan pengenalan masalah yang sesuai dengan situasi. Dengan mengajukan masalah konstektual, peserta didik secara bertahap di bimbing untuk menguasai konsep matematika. Untuk meningkatkan keefektifan pembelajaran, seharusnya sekolah menggunakan sarana, seperti komputer, alat peraga, atau media lainnya. Dalam pembelajaran matematika yang paling penting dilaksanakan adalah proses berfikir. Siswa dilatih untuk mengembangkan kemampuan berfikir logis, analitis, sistematis dan konsisten. Maka, pembelajaran yang sifatnya masih monoton dengan berbagai metode dan strategi harus di kembangkan agar tujuan pembelajaran dapat berjalan dengan baik.

Pendidikan kecakapan hidup yang mengatakan bahwa "pendidikan harus berdasarkan pada kebutuhan masyarakat secara luas dengan menekankan pada penguasaan Life Skills generik sebagai pondasi pengembangan lebih lanjut." Life Skills generik adalah pembagian atau penggolongan kecakapan hidup. Life Skills generik terdiri dari dua jenis, yaitu kecakapan personal yang mencakup kecakapan mengenal diri dan kecakapan perfikir rasional dan kecakapan sosial.(Anwar, 2012:29)

Sehingga Life Skills dapat didefinisikan sebagai kecakapan yang dimiliki oleh seseorang untuk berani menghadapi problem hidup dalam kehidupan dengan wajar tanpa merasa tertekan, kemudian secara proaktif dan kreatif mencari dan menemukan solusi untuk mengatasinya.
Dalam pembelajaran Life Skills proses pembelajaran harus dipandang sebagai stimulus yang dapat merangsang siswa untuk melaksanakan kegiatan belajar.

Berdasarkan uraian diatas, peneliti tertarik melakukan penelitian dengan judul "Efektivitas Penerapan Pendekatan Pembelajaran Life Skills terhadap Hasil Belajar Siswa Pokok Bahasan Garis Singgung Lingkaran Kelas VIII SMPN 4 Mataram Tahun Pelajaran 2013/2014".

Penelitian ini diharapkan mampu memberikan informasi bagi pengembangan pengetahuan pembelajaran yang berkaitan dengan penerapan pendekatan Life skills terhadap peningkatan hasil belajar siswa dan dapat menambah pengetahuan bagi peneliti dan lembaga, dan dapat dijadikan referensi bagi peneliti yang lain. Penelitian ini juga dijadikan sebagai motivasi untuk meningkatkan keterampilan memilih metode pendekatan pembelajaran yang sesuai dan bervariasi serta diharapkan dapat memberikan sumbangan yang bermanfaat bagi sekolah dengan adanya informasi yang diperoleh sehingga dapat dijadikan sebagai bahan kajian bersama agar dapat meningkatkan kualitas sekolah.

\section{LANDASAN TEORI}

Untuk dapat mengembangkan Life Skills (kecakapan hidup) pertama-tama seorang guru atau penulis mengetahui dulu mengapa dan apa pembelajaran Life Skills itu. Selanjutnya perlu diketahui bagaimana peran guru dalam melaksanakan pendekatan Life Skills serta didapatkan hasil yang bagaimanakah dalam proses pembelajaran khususnya pada bidang studi matematika dengan penmbelajaran Life Skills yang digunakan tersebut. Sebenarnya pembelajaran dengan pendekatan Life Skills merupakan panjabaran atau bagian dari kurikulum, yang merupakan inovasi dalam pembelajaran proses belajar mengajar antara guru dengan siswa akan tercipta atau terlaksana serta akan memperoleh hasil yang memuaskan (baik), apabila seorang guru mampu menciptakan suasana belajar yang kondusif, dalam arti mampu melaksanakan pendekatan yang baik dalam proses belajar mengajar tersebut.

Ungkapan ini sesuai dengan pendapat Anwar (2002:23) yang menyatakan bahwa "dalam mengajar, guru harus pandai menggunakan pendekatan secara aktif dan bijaksana, bukan sembarangan yang bisa merugikan anak didik. Pandangan guru 
terhadap anak didik akan menentukan sikap dan perbuatan. Sikap guru tidak selalu mempunyai pandangan yang sama dalam menilai anak didik. Hal ini akan mempengaruhi pendekatan yang guru ambil dalam pembelajaran.

Dari uraian diatas Life Skills dapat dikatakan sebagai pendekatan yang dapat memberikan kelebihan pada siswa agar dapat menjadi manusia yang tidak selalu tergantung dengan orang lain. Karena dia memiliki bekal keterampilan dan kecakapan hidup, baik kecakapan personal (Personal Skil), sosial, akademik, dan kecakapan vokasional, sehingga Life Skills dapat didefinisikan sebagai kecakapan yang dimiliki oleh seseorang untuk berani menghadapi problem hidup dan kehidupan dengan wajar tanpa merasa tertekan, kemudian secara proaktif dan kreatif mencari dan menemukan solusi untuk mengatasinya. Dalam pembelajaran Life Skills proses pembelajaran harus dipandang sebagai stimulus yang dapat merangsang siswa untuk melaksanakan kegiatan belajar. Peran guru banyak menempatkan diri sebaagai fasilitator belajar, dengan demikian siswa dapat melakukan kegiatan sendiri atau dalam bentuk kelompok untuk memecah permasalahan dengan bimbingan guru. Dalam pembelajaran pendekatan Life Skills ini siswa diberikan kesempatan untuk lebih berkreasi baik dalam mencari sendiri informasi maupun dibawah bimbingan guru. Sardiman menyatakan bahwa "pengajaran merupakan proses yang berfungsi membimbing para pelajar atau siswa dalam kehidupan yakni membimbing perkembangan diri sesuai dengan perkembangan yang harus dijalankan oleh para siswa itu".

Pembelajaran pendekatan Life Skills ini memiliki ciri-ciri sebagai berikut, yaitu:

1. Terjadi proses identifikasi keutuhan belajar

2. Terjadi penyadaran untuk belajar bersama

3. Terjadi keselarasan belajar kegiatan belajar untuk mengembangkan diri, belajar, usaha mandiri, dan usaha bersama.

4. Terjadi proses pemberian pengalaman dalam melakukan pekerjaan dengan benar, menghasilkan produk bermutu.

5. Terjadi proses interaksi saling belajar dari ahli

6. Terjadi penilaian kompetensi

7. Terjadi pendampingan teknis untuk bekerja atau membentuk usaha bersama.

Depdiknas (2002) membagi Life Skills

(kecakapan hidup) menjadi empat jenis yaitu:
1. Kecakapan personal (personal skills) yang mencakup kecakapan mengenai diri (self awarenesess) dan kecakapan berfikir rasional (social skills).

2. Kecakapan sosial (social skills).

3. Kecakapan akademik (academic skills).

4. Kecakapan vakasional (vakasional skills).

\section{METODE PENELITIAN}

Sesuai dengan tujuan penelitian maka dalam penelitian ini yang digunakan adalah metode eksperimen. Metode eksperimen dapat diartikan sebagai metode penelitian yang digunakan untuk mencari pengaruh perlakuan tertentu terhadap yang lain dalam kondisi yang terkendalikan (Sugiyono, 2012:72). Dengan kata lain penelitian eksperimen mencoba meneliti ada tidaknya hubungan sebab akibat dengan cara membandingkan satu atau lebih kelompok eksperimen yang diberi perlakuan.

Dalam penelitian ini desain penelitian yang akan digunakan adalah posttest-only control design. Kelompok pertama diberi perlakuan $(X)$ dan kelompok yang lain tidak. Kelompok yang diberi perlakuan disebut kelompok eksperimen dan kelompok yang tidak diberi perlakuan disebut kelompok kontrol. Pengaruh adanya perlakuan adalah $\left(\mathrm{O}_{1}: \mathrm{O}_{2}\right)$. Pengaruh perlakuan dianalisis dengan uji beda, uji t. (Sugiyono, 2012:76).

Penelitian ini dilaksanakan di SMPN 4 Mataram semester genap tahun pembelajaran 2013/2014. Adapun waktu penelitian ini akan dilaksanakan pada bulan Februari sampai Maret tahun pelajaran $2013 / 2014$.

Populasi dalam penelitian ini adalah seluruh siswa kelas VIII SMP Negeri 4 Mataram tahun pembelajaran 2013/2014, sedangkan sampel yang digunakan adalah sebanyak dua kelas, yaitu kelas $\mathrm{VIII}^{2}$ sebagai kelas kontrol dan sebagai kelas elsperimen. Adapun teknik pengambilan sampel pada penelitian ini adalah menggunakan Purposive sampling, dikenal juga dengan sampling pertimbangan yaitu teknik sampling dengan mengambil sampel dari anggota populasi yang dilakukan dengan pertimbangan-pertimbangan tertentu, (Riduan, 2013:62).

Dalam penelitian ini, peneliti menggunakan dua buah variabel yaitu variabel bebas (independen) dan variabel terikat (dependen). Variabel bebas adalah variabel yang mempengaruhi / menyebabkan timbulnya variabel terikat. Variabel bebas dalam penelitian 
ini adalah model pembelajaran. Sedangkan ariabel terikat adalah variabel yang dipengaruhi atau yang menjadi akibat karena adanya variabel bebas. Variabel terikat dalam penelitian ini adalah hasil belajar siswa dalam mata pelajaran matematika.

Instrumen yang digunakan dalam penelitian ini adalah tes. Terkait dengan tes, dalam penelitian ini yang digunakan adalah tes buatan guru. Peneliti menggunakan butir-butir soal tes yang terdiri dari 3 butir soal uraian/essay yang berkaitan dengan pokok bahasan yang bersangkutan. Hasil dari tes yang dilakukan digunakan untuk mengetahui hasil belajar siswa tentang Garis Singgung Lingkaran baik pada pre-test maupun pada posttest.

Adapun prosedur kerja dalam pelaksanaan penelitian ini adalah:

1. Melakukan observasi awal pada sekolah dan kelas yang akan diajarkan dengan pembelajaran dengan pendekatan Life Skills dan pembelajaran konvensional.

2. Mengumpulkan data awal berupa nilai ulangan semester terakhir dari guru mata pelajaran matematika kedua kelas kemudian dianalisis untuk menentukan kelas eksperimen dan kelas kontrol.

3. Melakukan kegiatan pembelajaran pada kedua kelas dengan waktu yang berbeda dan strategi yang berbeda pula.

4. Pada akhir pembelajaran, diberikan tes hasil belajar (posttest).

5. Selanjutnya menganalisis data yang telah terkumpul dari penelitian kemudian ditarik kesimpulan.

Teknik analisis data dalam penelitian kuantitatif menggunakan statistik. Terdapat dua macam statistik yang digunakan untuk menganalisis data penelitian, yaitu statistik deskriptif dan statistik inferensial. Statistik inferensial meliputi statistik parametris dan statistik nonparametris. Penggunaan statistik parametris dan nonparametris tergantung pada asumsi dan jenis data yang akan dianalisis. Statistik parametris kebanyakan digunakan untuk menganalisis data interval dan rasio, sedangkan statistik nonparametris kebanyakan digunakan untuk menganalisis data nominal, ordinal. (Sugiyono, 2012).

\section{A. Uji Normalitas Data}

Pengujian normalitas data dimaksudakan untuk mengetahui apakah distribusi sebuah data mengikuti atau mendekati distribusi normal. Terdapat beberapa teknik yang dapat digunakan untuk menguji normalitas data antara lain Kertas Peluang dan Chi Kuadrat. Dalam penelitian ini digunakan Chi Kuadrat untuk menguji normalitas data.

Rumus yang chi kuadrat :

$$
\chi^{2}=\sum_{i=1}^{k} \frac{\left(f_{0}-f_{h}\right)^{2}}{f_{h}}
$$

Keterangan :

$x^{2}=$ Chi Kuadrat

$f_{o}=$ frekuensi yang diobservasi

$f_{h}=$ frekuensi yang diharapankan. (Sugiyono, 2013:107)

Kriteria :

Apabila $x^{2}<X_{\text {tabel }}$ maka data dinyatakan berdistribusi normal dengan taraf signifikan $5 \%$

Apabila $x^{2}>X_{\text {tabel }}$ maka data dinyatakan berdistribusi tidak normal dengan taraf signifikan $5 \%$.

\section{B. Uji Homogenitas}

Uji homogenitas yang digunakan dalam penelitian ini yaitu dengan membandingkan hasil rata-rata yang diperoleh dari ke dua kelompok yaitu kelompok eksperimen dan kelompok kontrol. Uji homogenitas dimaksudkan untuk memperlihatkan bahwa dua atau lebih kelompok data sample berasal dari populasi yang memiliki varians yang sama. Pengujian Homogenitas dilakukan dengan menggunakan uji F.

Rumus uji F:

$$
F=\frac{S_{1}^{2}}{S_{2}^{2}}=\frac{\text { Varian Terbesar }}{\text { Varian Terkecil }}
$$

Varian masing kelas dicari dengan :

$$
S^{2}=\frac{n \sum f_{i} x_{i}^{2}-\left(\sum f_{i} x_{i}\right)^{2}}{n(n-1)}
$$

Keterangan :

$\mathrm{F}=$ Indeks homogenitas yang dicari

$S^{2}=$ Varians total

$f_{i} \equiv$ frekuensi

$x_{i}=$ Nilai tengah

Kesimpulan :

Jika $F_{\text {hitung }}<\mathrm{F}_{\text {tabel }}$ maka sampel homogen yaitu Ho diterima dan Ha ditolak. Jika $F_{\text {hitung }}>F_{\text {tabel }}$ 
maka sampel tidak homogen yaitu Ho ditolak dan Ha diterima. (Sugiyono, 2013:57).

Uji homogenitas sampel tersebut dilakukan untuk membuktikan bahwa perbandingan hasil belajar siswa betul-betul dipengaruhi oleh model pembelajaran yang telah diterapkan dan bukan dipengaruhi oleh faktor lain.

\section{Uji Hipotesis}

Hipotesis merupakan teori sementara yang kebenarannya masih perlu diuji. Mengingat bahwa hipotesis adalah jawaban sementara yang masih perlu diuji, maka hipotesis yang diajukan dalam penelitian ini masih harus diuji kebenarannya. Untuk keperluan pengujian hipotesis digunakan Uji Statistik yaitu Uji-t.

Adapun rumus $U j i$ t yang digunakan adalah:

a) Rumus Polled Varian

$$
t=\frac{\bar{X}_{1}-\bar{X}_{2}}{\sqrt{\frac{\left(n_{1}-1\right) S_{1}^{2}+\left(n_{2}-1\right) S_{2}^{2}}{n_{1}+n_{2}-2}\left[\frac{1}{n_{1}}+\frac{1}{n_{2}}\right]}}
$$

b) Rumus Separated Varians

Keterangan :

$$
t=\frac{\bar{X}_{1}-\bar{X}_{2}}{\sqrt{\frac{S_{1}^{2}}{n_{1}}+\frac{S_{2}^{2}}{n_{2}}}}
$$

$t=\mathrm{t}$ hitung

$\bar{X}_{1}=$ Nilai rata-rata kelompok eksperimen

$\bar{X}_{2}=$ Nilai rata-rata kelompok kontrol

$S^{2}=$ Varians kelas

$n=$ Jumlah sampel

Kedua rumus tersebut dapat digunakan apabila :

a. Bila jumlah anggota sampel $\mathrm{n}_{1}=\mathrm{n}_{2}$ dan varians homogen $\left(\sigma_{1}^{2}=\sigma_{2}^{2}\right)$ maka dapat digunakan kedua rumus t-test baik untuk separated maupun pool varian. Untuk melihat harga t table digunakan $\mathrm{dk}=\mathrm{n}_{1}+\mathrm{n}_{2}$ -2 .

b. Bila $\mathrm{n}_{1} \neq \mathrm{n}_{2}$, varian homogen $\left(\sigma_{1}^{2}=\sigma_{2}^{2}\right)$ dapat digunakan rumus t-test dengan polled varian dengan $d k=n_{1}+n_{2}-2$.

c. Bila $\mathrm{n}_{1}=\mathrm{n}_{2}$ dan varian tidak homogen $\left(\sigma_{1}^{2} \neq \sigma_{2}^{2}\right) \quad$ dapat digunakan rumus separated varian dan pooled varian dengan $\mathrm{dk}=\mathrm{n}_{1}-1$ atau $\mathrm{n}_{2}-2$.

d. Bila $\mathrm{n}_{1} \neq \mathrm{n}_{2}$ dan varian tidak homogeny $\left(\sigma_{1}^{2} \neq \sigma_{2}^{2}\right)$. Untuk ini digunakan rumus separated varian. Harga $t$ sebagai pengganti t tabel dihitung dari selisih harga $t$ tabel dengan $\mathrm{dk}=\mathrm{n}_{1}-1$ dan $\mathrm{dk}=\mathrm{n}_{2}-1$ dibagi dua, dan kemudian ditambah dengan harga t terkecil. (Sugiyono, 2013:138-139).

Kriteria :

Apabila t-hitung < t-tabel maka Ho diterima dan $\mathrm{Ha}$ ditolak dengan taraf signifikan $5 \%$. Apabila t-hitung > t-tabel maka Ho ditolak dan $\mathrm{Ha}$ diterima dengan taraf signifikan $5 \%$.

\section{HASIL PENELITIAN}

Data hasil penelitian diperoleh dari tes hasil belajar yang diberikan setelah adanya perlakuan kepada kedua kelompok. Tes menggunakan instrumen soal urain meteri Garis Singgung Lingkaran. Adapun deskripsi hasil belajar yang diperoleh kelas eksperimen dan kelas kontrol dapat dilihat pada tabel berikut:

Tabel 1. nilai rata-rata hasil belajar

\begin{tabular}{cccc}
\hline Kelas & $\begin{array}{c}\text { Nilai } \\
\text { tertinggi }\end{array}$ & $\begin{array}{c}\text { Nilai } \\
\text { terendah }\end{array}$ & $\begin{array}{c}\text { Rata- } \\
\text { rata }\end{array}$ \\
\hline Eksperimen & 98 & 38 & 58,90 \\
\hline Kontrol & 75 & 25 & 51,25 \\
\hline
\end{tabular}

Dari rata-rata data awal dan data hasil belajar kelompok eksperimen dan kelompok kontrol di atas, dapat ditabulasikan perbandingannya dalam tabel berikut ini:

Tabel 2. rata-rata data awal dan data hasil belajar kedua kelompok

\begin{tabular}{ccc}
\hline \multirow{2}{*}{ Kelas } & \multicolumn{2}{c}{ Rata-rata Nilai } \\
\cline { 2 - 3 } & Data awal & $\begin{array}{c}\text { Data hasil } \\
\text { belajar }\end{array}$ \\
\hline Eksperimen & 29,03 & 58,90 \\
\hline Kontrol & 28,83 & 51,25 \\
\hline
\end{tabular}

Adapun hasil uji t data hasil belajar dapat dilihat pada tabel berikut.

Tabel 3. Hasil Uji t Data Hasil Belajar

\begin{tabular}{lcccc}
\hline Nilai & Dk & $\begin{array}{c}\text { t- } \\
\text { hitung }\end{array}$ & $\begin{array}{l}\text { t- } \\
\text { tabel }\end{array}$ & $\begin{array}{c}\text { Keputus } \\
\text { an Uji }\end{array}$ \\
\hline $\begin{array}{l}\text { Data } \\
\text { hasil } \\
\text { belajar }\end{array}$ & 70 & 2,5483 & 1,994 & $\mathrm{H}_{0}$ ditolak \\
\hline
\end{tabular}


Dari tabel di atas terlihat bahwa nilai thitung $>$ t-tabel $(>1)$. Dengan demikian, $\mathrm{H}_{0}$ $\left(\mu_{1}=\mu_{2}\right)$ di tolak dan $\mathrm{H}_{1}\left(\mu_{1} \neq \mu_{2}\right)$ diterima. Artinya, "terdapat perbedaan hasil belajar matematika antara siswa kelas eksperimen yang diajar dengan menggunakan metode pembelajaran Life Skills dan siswa kelas kontrol yang diajar dengan menggunakan metode Konvensional materi garis singgung lingkaran pada siswa kelas VIII SMPN 4 Mataram.

\section{PEMBAHASAN}

Pada tahap awal penelitian, sebagai rujukan untuk mengetahui kemampuan awal siswa pada penelitian ini adalah data nilai ulangan umun kelas $\mathrm{VIII}^{2}$ dan kelas $\mathrm{VIII}^{4}$ semester I, kemudian dihitung nilai rata-rata masing-masing kelas untuk menentukan kelas eksperimen dan kelas kontrol.

Dari analisis data awal (nilai ulangan semester) di peroleh nilai rata-rata kelas VIII $^{2}$ 28,83 dan rata-rata kelas VIII $^{4} 29,03$. Hal ini menunjukan bahwa tidak terdapat perbedaan hasil belajar yang signifikan antara kedua kelas. Dan dapat dikatakan bahwa kedua kelompok berada dalam keadaan yang sama atau homogen. Berdasarkan hal tersebut maka dipilih kelas VIII ${ }^{4}$ sebagai kelas eksperimen dan kelas $\mathrm{VIII}^{2}$ sebagai kelas kontrol. Kemudian kedua kelas diberi perlakuan berbeda, kelas eksperimen diajar dengan menggunakan metode pembelajaran Life skills sedangkan kelas kontrol diajar dengan menggunakan metode konvensional (ceramah dan latihan)

Setelah diberikan perlakuan, kemudian diberikan tes hasil belajar. Dari data hasil belajar tersebut diperoleh nilai rata-rata kelas kontrol 51,25 sedangkan nilai rata-rata kelas eksperimen 58,90. Selanjutnya dilakukan uji normalitas untuk kelas eksperimen dan kelas kontrol, berdasarkan hasil perhitungan diperoleh bahwa data kedua kelas adalah berdistribusi normal. Begitu pula pada uji homogenitas dikethui bahwa kedua kelas

Pada uji hipotesis diperoleh $t_{\text {hitung }}=$ 2,5483 dan $t_{\text {tabel }}=1,994$. Karena $t_{\text {hitung }}>$ $t_{\text {tabel }}(2,5483>1,994)$ maka $\mathrm{H}_{0}$ ditolak sedangkan $\mathrm{H}_{1}$ diterima. Hal ini menunjukan bahwa terdapat perbedaan hasil belajar matematika yang signifikan antara siswa yang diajar dengan menggunakan metode pembelajaran Life Skills dengan siswa yang diajar dengan menggunakan metode ceramah dan latihan (konvensional).

Pembelajaran kelas eksperimen diterapkan dengan metode pembelajaran Life Skills. Pembelajaran dengan metode Life Skills pada jenjang sekolah menengah menekankan pada pengembangan kecakapan hidup generik yaitu mencakup kecakapan personal dan kecakapan sosial. Sehingga pada pembelajaran di kelas ekperimen, penerapannya dengan memberikan motivasi kepada siswa agar terdorong untuk mengembangkan kecakapan personal dan kecakapan sosialnya. Dengan pemanfaatan LKS dan alat peraga lainnya mengarahkan siswa untuk mengerjakan soal dengan tingkat kesulitan yang berbeda Keunggulan metode pembelajaran Life Skills ini adalah optimalisasi partisipasi siswa dalam proses pembelajaran sehingga siswa mau dan mampu untuk menyelesaikan permasalahan yang dihadapinya. Pada tahap menyajikan materi guru menjelaskan materi pokok Garis Singgung Lingkaran.

Pembelajaran yang dilaksanakan pada kelas kontrol adalah dengan menggunakan metode ceramah dan latihan (konvensional). Pembelajaran dengan metode meliputi pengajaran oleh guru berupa penyampaian materi-materi pembelajaran dan pemberian latihan berupa LKS untuk dikerjakan siswa secara mandiri. Dalam prosesnya guru lebih dominan dan berperan aktif dalam proses pembelajaran. Sedangkan siswa cenderung kurang aktif, hanya beberapa orang siwsa saja yang bertanya tentang materi pelajaran yang tidak mereka mengerti. Selebihnya hanya menerima apa yang disampaikan oleh guru. Dalam menyelesaikan tugas siswa yang lebih mampu merasa dapat menyelesaikan tugas sendiri, sedangkan siswa yang kurang mampu sering menyalin hasil kerja temannya.

Hasil belajar kelas eksperimen yang menggunakan metode pembelajaran Life Skills lebih baik karena siswa lebih mudah menentukan dan memahami konsep-konsep yang sulit yaitu dengan mengarahkan siswa dalam menyelesaikan masalah-masalah tersebut dengan temannya. Siswa juga tidak merasa bosan dan jenuh sehingga siswa terlibat secara aktif untuk mengikuti proses belajar mengajar. Namun demikian perlu disadari beberapa keterbatasan pada penelitian. Hasil analisis menunjukkan bahwa nilai rata-rata siswa kontrol juga mengalami peningkatan nilai. Hal ini kemungkinan terjadi karena adanya interaksi antara siswa pada kelompok eksperimen dengan siswa pada kelompok kontrol yang tidak dapat dipengaruhi oleh peneliti. Selain itu, peneliti juga tidak dapat 
mengontrol soal tes yang diberikan, untuk mengetahui tugas dikerjakan sendiri, dikerjakan oleh orang lain, atau mencontoh teman.

Pada pembelajaran Life Skills guru berperan sebagai fasilitator dan siswa memperoleh kesempatan untuk terlibat secara aktif dalam setiap kegiatan pembelajaran seperti bertanya, atas inisiatif sendiri maupun menjawab pertanyaan guru dan berdiskusi. Metode pembelajaran Life Skills dapat digunakan dalam kelas berjenjang namun demikian pembelajaran Life Skills mempunyai kelemahan-kelemahan. Dalam pelaksanaannya siswa yang aktif hanya siswa tertentu saja dan belum menyeluruh sehingga kesan pembelajaran searah masih terlihat dan siswa belum terbiasa dengan kondisi kelas pada saat proses pembelajaran.

Dengan adanya berbagai permasalahan tersebut perlu adanya perbaikan dalam proses pembelajaran selanjutnya yaitu, guru dapat lebih memotivasi siswa untuk mengungkapkan pendapatnya dengan cara bekerjasama dengan kelompoknya sehingga terjalinnya komunikasi yang baik antara siswa dalam kelompok untuk mengerjakan soal-soal latihan.

\section{SIMPULAN DAN SARAN}

A. Simpulan

Berdasarkan hal-hal yang telah

dikemukakan diatas, maka dapat disimpulkan beberapa hal yaitu sebagai berikut:

1. Terdapat perbedaan hasil belajar antara siswa yang diajar menggunakan metode pembelajaran Life Skills dengan siswa yang diajar menggunakan metode konvensional (ceramah dan latihan).

2. Hasil belajar matematika siswa yang diajar menggunakan metode pembelajaran Life Skills lebih baik dibanding hasil belajar matematika siswa yang diajar menggunakan metode konvensional pada materi Garis Singgung Lingkaran.

\section{B. Saran}

Berdasarkan hasil Penelitian yang telah dilakukan maka penulis mengajukan beberapa saran, antara lain :

1. Kepada sekolah dan pihak pengajar khususnya, hendaknya mempertimbangkan penggunaan metode pembelajaran Life Skills sebagai alternatif dalam proses pembelajaran untuk meningkatkan hasil belajar matematika siswa

2. Guru hendaknya membuat perencanaan yang matang dalam memilih materi dan mengalokasikan waktu dalam melaksanakan metode pembelajaran Life Skills.

3. Perlu penelitian lebih lanjut mengingat hasil penelitian masih sangat sederhana dan apa yang didapat dari hasil penelitian ini bukanlah merupakan hasil akhir karena masih memiliki banyak kekurangan.

\section{DAFTAR PUSTAKA}

Anurrahman. 2010. Belajar dan Pembelajaran. Bandung. Alfabeta

Arikunto, Suharsimi. 2010. Prosedur Penelitian Sebuah Pendekatan Praktik. Jakarta. Rineka Cipta

Anwar. 2012. Pendidikan Kecakapan Hidup. Bandung. Alfabeta.

Depdiknas. 2002. Kecakapaı, .idup Life Skills melalui pendekatan berbasis Luas. Bandung. Nusamedia.

Nuraini, Dewi \& Tri Wahyuni. 2008. Matematika Konsep dan Aplikasinya (untuk kelas VIII SMP dan MTs). Jakarta: Depdiknas

Riduwan. 2010. Metode Statistik Sosial. Bandung. Alfabta

Riduwan.2013. Metode dan Teknik Menyusun Tesis. Bandung.Alfabeta

Rumapea, Dormatio. 20113 . Model Pembelajaran Konvensional. http://dormatio.blogspot.com/2013/01/m odel-pembelajaran-konvensional.html, (diakses pada Minggu, 15 September 2013 pukul 14.12 WITA).

Sudjana, Nana. 2012. Penilaian Hasil Proses Belajar Mengajar. Jatim. SIC.

Sugiyono. 2012. Metode Penelitian Kuantitatif Kualitatif dan R\&D. Bandung. Alfabeta.

Tim Penyusun. (2012). Pedoman Penulisan Skripsi FKIP UM. Mataram. 